\title{
Occurrence and impacts of microplastics in freshwater fish
}

\begin{abstract}
Plastic production continues to increase as most developed and developing countries continue to adopt the use-and-dispose culture, while some try to implement regulations in the production and recycling of these materials. This high production associated with their durability, unsustainable use, and inappropriate waste management contributes to the introduction and extensive accumulation of plastic debris in natural habitats. Microplastics are of emerging concern, but the amount of research done in freshwater environments is nothing compared to that in marine environments. Following this reality, we seek to investigate the occurrence of these contaminants in freshwater fish and what are the possible impacts to these aquatic species and human beings, since we have a tight relation to this resource.
\end{abstract}

Keywords: Contamination, Fish, Freshwater, Microplastics, Impacts, Occurrence
Volume 5 Issue $6-2017$

\author{
Carlos Pinheiro, ${ }^{1,2}$ Oliveira $U^{1,2}$ Vieira $M^{1,2}$ \\ 'Departamento de Biologia, Faculdade de $\mathrm{Ci}$ \\ ${ }^{2}$ CIIMAR - Interdisciplinary Centre of Marine and Environmental \\ Research, Universidade do Porto, Portugal
}

Correspondence: Carlos Pinheiro, Faculdade de Ciências da Universidade do Porto, Rua do Campo Alegre S/N, 4169-007 Porto, Portugal, Tel +35I 912546 737,

Email cmpinheiro@fc.up.pt

Received: June 01, 2017 | Published: June 14, 2017
Abbreviations: MP, Microplastic; WWTP, Wastewater Treatment Plant; PCP, Personal Care Product; OPA, Organic Plastic Additives; POP, Persistent Organic Pollutants

\section{Introduction}

Plastic production continues to increase as most developed and developing countries continue to adopt the use-and-dispose culture, while some try to implement regulations in the production and recycling of these materials. Annual plastic production increased from 1.5 million tonnes in the 1950 s to 322 million tonnes in $2015,{ }^{1}$ bringing many societal benefits, in addition to medical and technological advances. ${ }^{2}$ However, this high production associated with their durability, unsustainable use, and inappropriate waste management contributes to the introduction and extensive accumulation of plastic debris in natural habitats, ${ }^{3}$ mainly in marine habitats where this problem is vastly documented. Here, macroplastics $(>25 \mathrm{~mm})$ are degraded into mesoplastics $(5-25 \mathrm{~mm})$ and then into microplastics (MPs), particles typically smaller than $5 \mathrm{~mm}$ in diameter. Besides these degradation products (secondary MPs), MPs can also be produced (primary MPs), ${ }^{4}$ these include microbeads, resin pellets or personal care products (PCPs).

MPs are of special concern since their bioavailability increases with decreasing size, making them easily available to lower trophic organisms. ${ }^{5}$ Many of these organisms capture anything of appropriate size without being able to select between particles. ${ }^{6}$ In addition, MPs contain a variety of organic plastic additives $(\mathrm{OPAs})^{7}$ and have also been shown to adsorb persistent organic pollutants (POPs) from the surrounding seawater (briefly reviewed by Bakir et al., ${ }^{8}$ ), potentially affecting all organisms throughout the aquatic food web. ${ }^{9}$

Marine plastic pollution has been of concern since the late 1960's ${ }^{10}$ and early 70 's, ${ }^{11}$ when the first reports of MPs ingestion were starting to be published. On the other hand, it has only recently been carried out studies that highlight the contamination of freshwater ecosystems by MPs, as reviewed by Wagner et al. ${ }^{4}$ Nonetheless, information is still scarce and spread regarding freshwater environments and, especially, freshwater fauna.

Fish are an important biological element of the freshwater ecosystems with significant economic and nutritional value worldwide. About $94 \%$ of all freshwater fisheries occur in developing countries, ${ }^{12}$ providing food and a livelihood for millions of the world's poorest people, and contributing to the overall economic wellbeing by means of exportation, tourism, and recreation. ${ }^{13}$ Moreover, they generate many ecosystem-services such as: (1) regulating food web dynamics and nutrient balances; (2) regulating carbon flux; (3) regulating sediment processes and (4) are links between ecosystems. ${ }^{14}$ Thus, it becomes vital to protect and preserve freshwater fish populations from contaminants of emerging concern like microplastics.

Therefore, our work seeks to investigate the occurrence of these contaminants in freshwater fish around the world and what are the possible impacts to these aquatic species and human beings since we have a tight relation to this resource.

\section{Early works}

\section{Occurrence of Microplastics in Freshwater Fish}

Despite the greater knowledge on marine microplastics, to date, only five studies have investigated the occurrence of MPs in freshwater fish.

In a 2014 preliminary field report, Sanchez et al. ${ }^{15}$ provided the first evidence that freshwater fish ingest MPs. They investigated wild gudgeons (Gobio gobio) caught in 11 French streams, characterized by various environmental pressures, and found MPs in the digestive tract of $12 \%$ of the fish.

Phillips \& Bonner ${ }^{16}$ also documented the occurrence of plastic ingested by fishes in freshwater drainages of the Gulf of Mexico with a percent occurrence of MP ingestion of $8 \%$. Later, Peters \& Bratton ${ }^{17}$ found that $45 \%$ of the fish sampled had ingested MPs within the Central Brazos River Basin, Texas. More recently, Jabeen et al. ${ }^{18}$ studied micro- and mesoplastic pollution in sea and freshwater fishes from China, finding MPs in $95.7 \%$ of freshwater fish. They also reported for the first time the abundance of plastics in the intestines suggesting that the abundance of plastics in the intestines was even higher than in the stomachs in some fish species. In the same issue, Silva-Cavalcanti et al. ${ }^{19}$ assessed the ingestion of MPs by Hoplosternum littorale, a common freshwater fish consumed daily by 
humans, in the Northeast Brazil. Fish were caught in four sampling sites in a city-crossing section of the Pajeú river finding MPs in the digestive system of $83 \%$ of the fish, a proportion far above from those reported for another freshwater, estuarine or even marine fish. ${ }^{19}$

\section{Impacts of Microplastics in Freshwater Fish}

Within ecosystems, microplastics can have quite harmful consequences for the local fauna. Ingestion of plastic particles has been reported for over 600 taxa, ${ }^{21}$ being fish among the most affected taxa. Ingestion is the most common form of fish contamination by MPs. It is thought that their ingestion may occur intentionally, as they are mistaken for small food particles suspended in the water column; accidentally, when they ingest it with food or even preferentially, as is the case of Perca fluviatilis' larvae. ${ }^{17,22,23}$

Several studies have demonstrated the negative effects of MPs on fish fauna, from physical to physiological effects ${ }^{3,23,24}$ The physical risks inherent to its ingestion include the clogging of the alimentary appendages and of the digestive system, and inflammation and laceration of gastrointestinal tissues preventing the correct absorption of nutrients. ${ }^{24-27}$ The physiological interference can also be observed when MPs directly interfere with the immune system of fish through the stimulation of degranulation ${ }^{28}$ and through behavioural change, reducing the ability of a predator to perceive. ${ }^{23}$

Table I Species of freshwater fish in which microplastics were found

\begin{tabular}{|c|c|c|}
\hline \multirow{2}{*}{$\begin{array}{l}\text { Family } \\
\text { Callichthyidae }\end{array}$} & Species & Reference \\
\hline & Hoplosternum littorale Hancock, I828 & [19] \\
\hline Centrarchidae & $\begin{array}{l}\text { Lepomis auritus Linnaeus, I758 } \\
\text { Lepomis cyanellus Rafinesque, I819 } \\
\text { Lepomis humilis Girard, I858 } \\
\text { Lepomis macrochirus Rafinesque, I819 } \\
\text { Lepomis megalotis Rafinesque, I820 } \\
\text { Lepomis microlophus Günther, I859 } \\
\text { Micropterus salmoides Lacepède, I802 }\end{array}$ & $\begin{array}{l}{[16]} \\
{[16]} \\
{[16]} \\
{[16,17]} \\
{[16,17]} \\
{[16]} \\
{[16]}\end{array}$ \\
\hline Characidae & Astyanax mexicanus De Filippi, 1853 & [16] \\
\hline Cichlidae & $\begin{array}{l}\text { Herichthys cyanoguttatus Baird \& Girard, I } 854 \\
\text { Oreochromis aureus Steindachner, I } 864\end{array}$ & $\begin{array}{l}{[16]} \\
{[16]}\end{array}$ \\
\hline Clupeidae & $\begin{array}{l}\text { Dorosoma cepedianum Lesueur, I8I8 } \\
\text { Dorosoma petenense Günther, } 1867\end{array}$ & $\begin{array}{l}{[16]} \\
{[16]}\end{array}$ \\
\hline Cyprinidae & $\begin{array}{l}\text { Campostoma anomalum Rafinesque, I820 } \\
\text { Carassius auratus Linnaeus, I } 758 \\
\text { Cyprinella lutrensis Baird \& Girard, I853 } \\
\text { Cyprinella venusta Girard, I } 856 \\
\text { Cyprinus carpio Linnaeus, I } 758 \\
\text { Gobio gobio Linnaeus, I } 758 \\
\text { Hemiculter bleekeri Warpachowski, I } 888 \\
\text { Hypophthalmichthys molitrix Valenciennes, I844 } \\
\text { Megalobrama amblycephala Yih, I } 955 \\
\text { Notropis amabilisGirard, I } 856 \\
\text { Notropis sabinae Jordan \& Gilbert, I886 } \\
\text { Notropis stramineus Cope, I } 865 \\
\text { Notropis volucellus Cope, I } 865 \\
\text { Pimephales vigilax Baird \& Girard, I853 } \\
\text { Pseudorasbora parva Temminck and Schlegel, I846 }\end{array}$ & $\begin{array}{l}{[16]} \\
{[18]} \\
{[16]} \\
{[16]} \\
{[18]} \\
{[15]} \\
{[18]} \\
{[18]} \\
{[18]} \\
{[16]} \\
{[16]} \\
{[16]} \\
{[16]} \\
{[16]} \\
{[18]}\end{array}$ \\
\hline Fundulidae & Fundulus notatus Rafinesque, 1820 & [16] \\
\hline Ictaluridae & $\begin{array}{l}\text { Ameiurus natalis Lesueur, } 1819 \\
\text { Ictalurus punctatus Rafinesque, } 1818 \\
\text { Noturus gyrinus Mitchill, } 1817\end{array}$ & $\begin{array}{l}{[16]} \\
{[16]} \\
{[16]}\end{array}$ \\
\hline Percidae & Etheostoma artesiae Hay, I88I & [16] \\
\hline Poeciliidae & Gambusia affinis Baird \& Girard, 1853 & {$[16]$} \\
\hline
\end{tabular}

From all the plastic morphotypes studied, fibres were the most microfibres are more flexible and smaller being more likely to be predominant in every work. Compared to larger plastic particles, ingested accidentally throughout the trophic chain or mixed with

\section{Observations and discussion}

In view of the above work, MPs were present in 34 different species from all around the world (Table 1). Although the number of examined species is considerably low, it is also expected since some authors chose to select sentinel species based on their: (1) use in ecotoxicology and life cycle traits ${ }^{15}(2)$ abundance throughout the study area, sampling accessibility and position within the food chain ${ }^{17}$ and (3) demand as a highly consumed fishing resource. ${ }^{19}$

All the results obtained in the studies suggested that fish inhabiting freshwater environments near urbanized areas were at a higher risk of exposure to and ingestion of MPs, except Jabeen et al., ${ }^{18}$ whose study focused in the relationship between plastic pollution and the feeding traits and habitats of freshwater fish. Silva-Cavalcanti et al. ${ }^{19}$ observed MPs were ingested more frequently in fish collected at stations that were more densely urbanized. Both, Phillips \& Bonner ${ }^{16}$ and Peters \& Bratton ${ }^{17}$ showed that several fish species collected in rivers near urbanized areas in Texas showed a significantly higher proportion of ingestion of plastic debris in relation to fish caught in less urbanized areas Sanchez et al. ${ }^{15}$ did not detect MPs in wild gudgeons from low impacted sites located in watersheds' upstream areas, while those collected from urban rivers had MPs in their gut, thus supplementing the hypothesis that wastewater treatment plants (WWTPs), in urbanized areas, are one of the sources of MPs in inland surface waters. ${ }^{20}$ 
sediments. ${ }^{19}$ For instance, microfibres have been observed in the guts of several gudgeons from French rivers, ${ }^{15}$ in fish species from Texas rivers ${ }^{16}$ and in Hoplosternum littorale. ${ }^{19}$ Also, $96 \%$ of all plastic particles ingested by Centrarchidae fish from the Brazos river in the Texas were microfibers, ${ }^{17}$ and in some fish species found in China microfibres represented $26.3-88.2 \%$ of all the plastic ingested. ${ }^{18}$

Jabeen et al. $^{18}$ found demersal species showed significantly higher abundance of plastics than pelagic fishes $(p<0.05)$, saying, afterwards, that freshwater fish feeding habits and habitats play an important role in the ingestion of plastic debris. Silva-Cavalcanti et al. ${ }^{19}$ corroborated this interaction by relating the feeding trait of $\mathrm{H}$. littorale, a microphagous scavenger, with the accidental ingestion of plastic debris mixed with sediment when foraging on the bottom for food. Furthermore, Sanchez et al. ${ }^{15}$ related the higher ingestion of plastic debris, by Gobio gobio, with its bottom feeding behaviour.

Microplastics have several properties, and believed to have effect on organisms directly or indirectly, working as a vehicle of chemical substances. These chemical impacts of the MPs structure are complex and works at different levels. Because polymers are molecules of high dimensions, they are biochemically stable. However, the polymerization reaction is rarely complete, evidencing the presence of residual monomers which varies up to $4 \% .{ }^{29}$ These monomers can be leached from the polymer matrix and many of them can be considered toxic to the environment, evidenced by the ranking of Lithner et al. ${ }^{30}$ In addition to the effects of its structural matrix, the toxic effects can be caused by the chemical additives inserted during its manufacturing process, such as solvents and catalysts, as well as plasticizers and antimicrobial agents, which are part of the structure of the final composition of the plastic. As these components have low molecular weight, they can easily migrate or diffuse into the environment causing adverse effects on the ecosystem. ${ }^{31}$

The affinity of the organic contaminants to the plastic matrix leads to its accumulation and absorption ${ }^{32,33}$ acting in a similar way to the chemical additives. However, studies that substantiate these impacts to the fish fauna are limited. Study conducted by Lönnstedt \& Eklöv, ${ }^{23}$ which shows that the exposure of larvae of Perca fluviatilis to plastic polymers does not respond to threat stimulate by inducing the predator mortality rate. However, such a study does not clearly demonstrate whether the effects are on exposure responses of chemical or physical contaminants from MPs. Differently from the study conducted by Browne et al. ${ }^{34}$ that exposes Arenicola marina sand contaminated with MPs demonstrating a tissue accumulation of $250 \%$ of the contaminants. Thus, there is a great limitation of information regarding the exposure of chemical contaminants by parts of the MPs associated with fish fauna, being of major importance further studies to determine the impacts of chemical and organic pollutants from plastic polymers in the aquatic ecosystem of water candy.

\section{Gaps in research}

Most rivers with a high rate of plastic debris are located close to large urban centres, presenting a great risk to fish biodiversity and especially to general fish ${ }^{17,35}$ and are related to the consumer market. In this way, the presence of MPs in fish consumption has raised a great problem in the potential of transference to humans, ${ }^{36}$ since MPs are vectors of dispersion of several types of contaminants, increasing their proportion of thousands of times along the trophic chain through biomagnification. ${ }^{37,38}$

Although many studies involving the MP related to marine environments, in recent years there have been many studies regarding freshwater environments that aim to relate their presence with possible impacts to local fauna. However, there is a limitation of studies that evidence the impacts of MPs on the long trophic chain being humans the final receivers. Thus, if the severity of adverse effects on the ecosystem is severe enough to favour population decline, food security will be compromised.

\section{Conclusion}

From our review, we can conclude that freshwater fish are extremely vulnerable to microplastics pollution and that urbanized areas appear to be a major factor contributing to the pollution of freshwater environments with MPs. Nevertheless, there only exists a handful number of articles reporting these situations. Moreover, the lack of standard protocols makes it difficult to replicate the data and, consequently, validate it. Also, more information on the transportation of MPs throughout the food chain and subsequently the possible impacts in each population are importantly in demand.

The investigation of MPs in aquatic environments is a highly dynamic and interdisciplinary area of research that, in recent years, as advanced our understanding of the environmental impact of this emerging concern. ${ }^{4}$ However, nowadays research is still focused almost on marine MP with a lot of scarce data on freshwater ecosystems as we showed in our review. We hope that in the future the knowledge gaps that still exist regarding MPs in freshwaters are mitigated with the help of environmental and financial incentive provided by environmental agencies.

\section{Acknowledgements}

This article is a result of the project INNOVMAR - Innovation and Sustainability in the Management and Exploitation of Marine Resources (reference NORTE-01-0145-FEDER-000035, within RL ECOSERVICES), supported by NORTE 2020, under the PORTUGAL 2020 Partnership Agreement, through the ERDF.

\section{Conflicts of interest}

None.

\section{References}

1. PlasticsEurope. Plastics - the Facts 2016: An analysis of European plastics production, demand and waste data. Plastic Europe. 2016.

2. Andrady AL, Neal MA. Applications and societal benefits of plastics. Philos Trans R Soc Lond B Biol Sci. 2009;364(1526):1977-1984.

3. Barnes DKA, Galgani F, Thompson RC, et al. Accumulation and fragmentation of plastic debris in global environments. Philosophical Transactions of the Royal Society B-Biological Sciences. 2009;364(1526):1985-1998.

4. Wagner M, Scherer C, Alvarez-Muñoz D, et al. Microplastics in freshwater ecosystems: what we know and what we need to know. Environmental Sciences Europe. 2014;26(12).

5. Wright SL, Thompson RC, Galloway TS. The physical impacts of microplastics on marine organisms: A review. Environmental Pollution. 2013; 178:483-492.

6. Moore CJ. Synthetic polymers in the marine environment: A rapidly increasing, long-term threat. Environmental Research. 2008;108(2):131-139.

7. Dekiff JH, Remy D, Klasmeier J, et al. Occurrence and spatial distribution of microplastics in sediments from Norderney. Environ Pollut. 2014;186:248-256. 
8. Bakir A, Rowland SJ, Thompson RC. Competitive sorption of persistent organic pollutants onto microplastics in the marine environment. Mar Pollut Bull. 2012;64(12):2782-2789.

9. Zarfl C, Matthies M. Are marine plastic particles transport vectors for organic pollutants to the Arctic? Marine Pollution Bulletin. 2010;60(10):1810-1814.

10. Kenyon KW, Kridler E. Laysan Albatrosses Swallow Indigestible Matter. Auk. 1969;86(2):339.

11. Carpente Ej, Anderson SJ, Miklas HP, et al. Polystyrene Spherules in Coastal Waters. Science. 1972;178(4062):749-750.

12. FAO. The state of world Aquaculture and Fisheries 2006. Food and Agriculture Organization of the United Nations. Fisheries and Aquaculture Department. Rome, Italy. 2007.

13. Fish: An Issue for Everyone. A Concept Paper for Fish for All, Worldfish Center. 2002.

14. Holmlund CM, Hammer M. Ecosystem services generated by fish populations. Ecological Economics. 1999;29(2):253-268.

15. Sanchez W, Bender C, Porcher JM. Wild gudgeons (Gobio gobio) from French rivers are contaminated by microplastics: Preliminary study and first evidence. Environ Res. 2014;128:98-100.

16. Phillips MB, Bonner TH. Occurrence and amount of microplastic ingested by fishes in watersheds of the Gulf of Mexico. Marine Pollution Bulletin. 2015;100(1):264-269.

17. Peters CA, Bratton SP. Urbanization is a major influence on microplastic ingestion by sunfish in the Brazos River Basin, Central Texas, USA. Environ Pollut. 2016;210:380-387.

18. Jabeen K, Su L, Li JN, et al. Microplastics and mesoplastics in fish from coastal and fresh waters of China. Environ Pollut. 2017;221:141-149.

19. Silva-Cavalcanti JS, Silva JD, França EJ, et al. Microplastics ingestion by a common tropical freshwater fishing resource. Environ Pollut. 2017;221:218-226.

20. GESAMP Joint Group of Experts on the Scientific Aspects of Marine Environmental Protection): Proceedings of the GESAMP international workshop on micro-plastic particles as a vector in transporting persistent, bio-accumulating and toxic substances in the oceans. In: GESAMP Reports \& Studies Bowmer T, Kershaw P (Eds.), Paris: UNESCO-IOC. 2010;pp.68.

21. Secretariat of the Convention on Biological Diversity. Marine biodiversity - One ocean, many worlds of life. Montreal, Canada. 2012.

22. Cole M, Lindeque P, Halsband C, et al. Microplastics as contaminants in the marine environment: A review. Marine Pollution Bulletin. 2011;62(12):2588-2597.

23. Lonnstedt OM, Eklov P. Environmentally relevant concentrations of microplastic particles influence larval fish ecology. Science. 2016;352(6290):1213-1216.

24. Pedà C, Caccamo L, Fossi MC, et al. Intestinal alterations in European sea bass Dicentrarchus labrax (Linnaeus, 1758) exposed to microplastics: Preliminary results. Environ Pollut. 2016;212:251-256.
25. Laist D W. Impacts of marine debris: entanglement of marine life in marine debris including a comprehensive list of species with entanglement and ingestion records. In: JM Coe, BD Rogers (Eds.), Marine debris: sources, impacts and solutions, p. 99-141. Berlin, Germany: Springer. 1997.

26. Rochman CM, Browne MA, Halpern BS, et al. Classify plastic waste as hazardous. Nature. 2013;494(7436):169-171.

27. Lusher AL, McHugh M, Thompson RC. Occurrence of microplastics in the gastrointestinal tract of pelagic and demersal fish from the English Channel. Marine Pollution Bulletin. 2013;67(1-2):94-99.

28. Greven AC, Merk T, Karagoz F, et al. Polycarbonate and Polystyrene Nanoplastic Particles Act as Stressors to the Innate Immune System of Fathead Minnow (Pimephales Promelas). Environ Toxicol Chem. 2016;35(12):3093-3100.

29. Araujo PHH, Sayer C, Poco JGR, et al. Techniques for reducing residual monomer content in polymers: A review. Polymer Engineering and Science. 2002;42(7):1442-1468.

30. Lithner D, Larsson A, Dave G. Environmental and health hazard ranking and assessment of plastic polymers based on chemical composition. Sci Total Environ. 2011;409(18):3309-3324.

31. Crompton TR. Additive Migration from Plastic into Food: a Guide for the Analytical Chemist. Smithers Rapra Technology Limited, Shawsbury, Shrewbury, Shropshire. 2007;pp.312

32. Ziccardi LM, Edgington A, Hentz K, et al. Microplastics as vectors for bioaccumulation of hydrophobic organic chemicals in the marine environment: A state-of-the-science review. Environ Toxicol Chem. 2016;35(7):1667-1676.

33. Holmes LA, Turner A, Thompson RC. Adsorption of trace metals to plastic resin pellets in the marine environment. Environ Pollut. 2012;160:42-48.

34. Browne MA, Niven SJ, Galloway TS, et al. Microplastic Moves Pollutants and Additives to Worms, Reducing Functions Linked to Health and Biodiversity. Curr Biolo. 2013;23(23):2388-2392.

35. Lowe-Mcconnell RH. Ecological Studies in Tropical Fish communities (1stedn), Cambridge University Press, USA. 1987;pp .400.

36. Rochman CM, Tahir A, Williams SL, et al. Anthropogenic debris in seafood: Plastic debris and fibers from textiles in fish and bivalves sold for human consumption. Scientific Reports, 5. 2015

37. Mato $\mathrm{Y}$, Isobe $\mathrm{T}$, Takada $\mathrm{H}$, et al. Plastic resin pellets as a transport medium for toxic chemicals in the marine environment. Environ Sci \& Technol. 2001;35(2):318-324.

38. Cabana G, Tremblay A, Kalff J, et al. Pelagic Food-Chain Structure in Ontario Lakes - A Determinant of Mercury Levels in Lake Trout (Salvelinus-Namaycush). Canadian Journal of Fisheries and Aquatic Sciences. 1994;51(2):381-389. 